\title{
Potential Health Risk Assessment for the Occurrence of Heavy Metals in Rice field Influenced by Landfill Activity in Can Tho City, Vietnam
}

\author{
Nguyen Thanh Giao
}

\author{
College of Environment and Natural Resources, Can Tho University, Can Tho city, Vietnam \\ *Corresponding author
}

\begin{abstract}
The study was conducted to assess potential risk of heavy metals in the soil and rice plants in the ricefield around the landfill in Dong Thang commune, Co Do district, Can Tho city, Vietnam. Four soil samples in which three samples were collected around the landfill and one sample was collected one km away from the landfill for the analysis of heavy metals including $\mathrm{Mn}, \mathrm{Zn}, \mathrm{Cu}, \mathrm{Cr}, \mathrm{Ni}, \mathrm{Pb}$ and $\mathrm{Cd}$. Rice samples were collected during ripening stage (few days before the harvest) at the same locations with the soil sampling, for the same heavy metal species analysis. The findings revealed that six out of seven heavy metals occurred in the soil.The decreasing order of theheavy metals concentrationsin the soil samples was $\mathrm{Mn}>\mathrm{Zn}>\mathrm{Ni}>\mathrm{Cr}>\mathrm{Cu}>\mathrm{Pb}$. This study found that accumulation of heavy metals in parts of rice at S1-S3 was higher that those at $\mathrm{S} 4$ (except for $\mathrm{Zn}$ and $\mathrm{Pb}$ at rice roots) and decreased in the order $\mathrm{Mn}>\mathrm{Zn}>\mathrm{Cu}>$ $\mathrm{Ni}>\mathrm{Cr}$ (except in rice grain, $\mathrm{Cr}>\mathrm{Cu}>\mathrm{Ni}$ ). Heavy metalsgenerally in the rice partswere in the magnitude order of root > stem-leave> grain. The calculated hazard index (HI) indicated that the accumulation of heavy metals in soil and rice grain is not likely to pose a threat to public health $(H I<1)$, however, potential health and ecological risk may still exist. Measures should be taken to prevent landfill leachate leaching into the agricultural areas to minimize potential environmental and health risks.
\end{abstract}

Keywords_Landfill; leachate; heavy metals; health risk; ricefield.

\section{INTRODUCTION}

Vietnam has recently been facing serious environmental pollution from solid wastes as the amounts of generated wasteshave been increasing in both quantity and toxic level. According to the National Environmental Report 2011-2015 (MONRE, 2015), the total amount of urban domestic solid waste generated in the country was 32,000 tons in 2014. The amount of solid waste generated in the Mekong Delta region accounted for 5\% of the generation of the whole country. Can Tho city is generatingsolid wastes of approximate 893 tons day ${ }^{1}$ (People's Committee of Can Tho City, 2015). Solid wastes have been collected and treated at landfills. However, landfills have also been identified as a cause of soil and groundwater pollution(Fatta et al., 1999). According to MONRE (2015), only 203 out of 660 landfills across the country are sanitary landfills, and the remaining were unsanitary. However, the majority of landfills have been overloaded, exacerbating the environmental impacts, which has led to increasingly serious and complex pollution problem in the landfilling areas.

The landfill at Dong Thang Commune, Co Do District, Can Tho City, Vietnam is in a state of serious overload due to receiving a fairly large amount of waste approximate 370 tons per day ${ }^{-1}$ from several districts of Can Tho city. The untreated leachate has significantly affected water quality, soil and rice yield in the land adjacent to the landfill (Nhien and Giao, 2019). Leachate not only contains high levels of organic matter, nitrogen but also significant concentrations of heavy metals, so it may cause pollution of soil and surface water (Nhien and Giao, 2019). Several studies have also shown that heavy metals are often found in high concentrations in and around landfills all over the world (Alam et al., 2012; NavaMartinez et al., 2012; Ajah et al., 2015). In addition, 
heavy metals could potentially present in paddy fields due to impurities of chemical fertilizers and pesticides (Liu et al., 2003; Kingsawat and Roachanakanan, 2011). Therefore, heavy metal contamination is always a major focus in several environmental studiessince it could bioaccumulate in microorganisms and then transfer into food chains, for example, from plant to animal and to human being(Munees and Abdul, 2012; Klinsawathom et al., 2017). The former study pointed out that heavy metals could move from soil and water to plants' tissues via uptakingby roots (Kingsawat and Roachanakanan, 2011), posingpotential risks for human health and ecosystems(Satachon et al., 2019).Currently, several studies reported on the quality of water and soil at the landfill and surrounding areas (Kanmani and Gandhimathi, 2013; Huang et al., 2013; Nhien and Giao, 2019) but very few studies have been carried out on assessment of potential risk resulting from exposure to heavy metals in rice grains and soil.This study was implemented to examine the potential risk for the presence of heavy metals in soil and rice parts around Dong Thang landfill, Co Do district, Can Tho city, Vietnam. The findings from this study could provide useful information for local authorities for managing risk resulting from heavy metal occurrence.

\section{MATERIALS AND METHODS}

\section{1) Soil sampling and analysis}

Soil samples were collected at the depth of 0-25 $\mathrm{cm}$ at 4 locations, of which 3 locations in the rice field surrounding the landfill (namely S1, S2, S3) and 1 locationin the ricefield $1 \mathrm{~km}$ away from the landfill (namely S4) (Figure 1). After the collection, the soil samples were dried at room temperature, pulverized and sieved through mesh with the pore size of $0.5 \mathrm{~mm}$ for heavy metal analysis. The pulverized soil sample $(0.5 \mathrm{~g})$ was digested using a microwave digester (Microwave digester, Milestone, Ethos) using the method of the United State Environmental Protection Agency (EPA3051) by adding $10 \mathrm{ml}$ of $65 \%$ nitric acid and operated at 1,000 watts of power, temperature of $175^{\circ} \mathrm{C}$ for 15 minutes 30 seconds. Heavy metals including $\mathrm{Cd}, \mathrm{Cr}, \mathrm{Cu}, \mathrm{Fe}, \mathrm{Ni}, \mathrm{Mn}, \mathrm{Pb}$ and $\mathrm{Zn}$ were determined by atomic absorption spectrometry (AAS, Agilent, AA240). All glasswares used in heavy metal analysis were cleaned washed using $0.1 \mathrm{M}$ nitric acid for 24 hours and then rinsed with distilled water. Analysis of heavy metals was performed in triplicates.

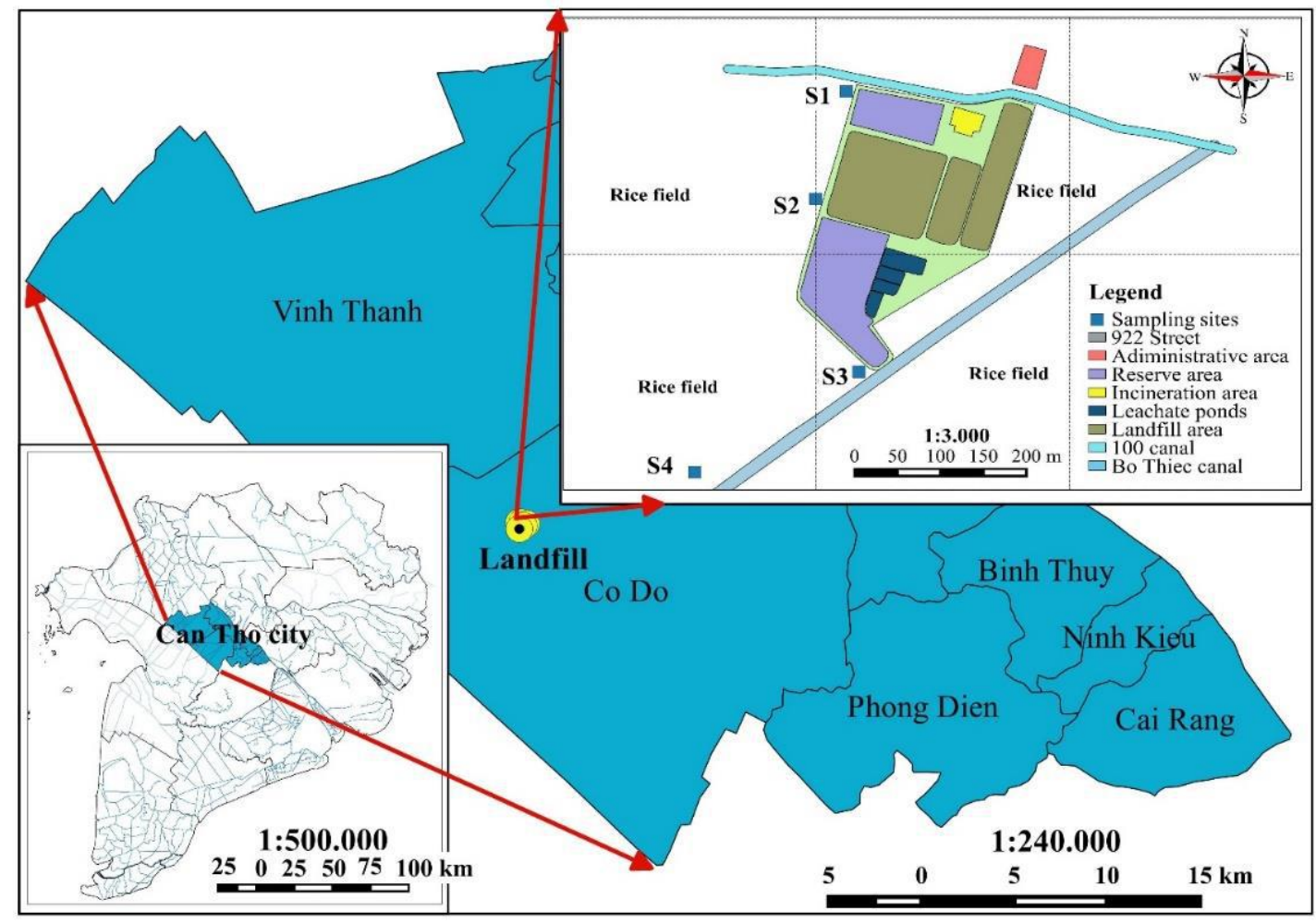

Fig.1: Soil sampling locations. 


\section{2) Rice sample collection and analysis for heavy metals}

Rice samples were collected during ripening stage (few days before the harvest) at the same locations with the soil sampling (Figure 1). Five whole rice plants were carefully removed from soil at five positions in an area of 1 $\mathrm{m}^{2}$ for every sampling location. The collected rice plants were divided into three parts including the root, stem and leave, and grain. The separated parts of the rice plants at three locations surrounding landfill (S1, S2, and S3) were pooled to reduce the analysis cost due to limited budget. The heavy metals including $\mathrm{Cd}, \mathrm{Cr}, \mathrm{Cu}, \mathrm{Ni}, \mathrm{Mn}, \mathrm{Pb}$ and $\mathrm{Zn}$ were analyzed in the rice parts. The procedure for analyzing heavy metals in rice samples was performed in the similar manner to that for analyzing soil samples.

\section{3) Risk assessment}

Hazard index (HI) due to heavy metals in soil and rice (grain) was assessed according to Hang et al. (2009) and Ferreira- Baptista and de Miguel (2005). Heavy metal enters the body daily (D) through the three main routes including ingestion ( $\left.D_{\text {ing }}\right)$, inhalation $\left(D_{\text {inh }}\right)$, and dermal contact $\left(D_{\text {der }}\right)$. Heavy metalsin rice grain only enter the body through ingestion $\left(\mathrm{D}_{\text {ing }}\right)$. Daily consumption levels through different contact routes were calculated based on Equation 2, 3, and 4.

- Direct ingestion rice grain $\left(D_{\text {ing }}\right)$ :

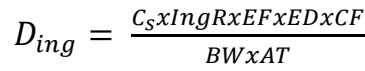

- Inhalation of suspended particles via mouth and noise $\left(\mathrm{D}_{\text {inh }}\right)$ :

$D_{\text {inh }}=\frac{C_{S} \times I n h R \times E F x E D}{B W x A T x P E F}$

- Dermal contact $\left(\mathrm{D}_{\mathrm{der}}\right)$ :

$$
D_{d e r}=\frac{C_{S} x S A x S L x A B S x E F x E D x C F}{B W x A T}(\mathrm{Eq} .4)
$$

Where: $\mathrm{C}_{\mathrm{s}}$ is concentration of pollutants in soil or rice $(\mathrm{mg} / \mathrm{kg})$; IngR is the rate of ingestion of pollutants in soil or rice $\left(\mathrm{mg} \mathrm{day}^{-1}\right)$; InhR is inhalation rate of suspended particles in soil $\left(\mathrm{m}^{3} \mathrm{day}^{-1}\right)$; EF and ED are frequency of exposure (dayyear-1 ${ }^{-1}$ and duration of exposure (years); $\mathrm{CF}$ is conversion factor $=1.00 \mathrm{E}-06\left(\mathrm{~kg} \mathrm{mg}^{-1}\right)$ and, $\mathrm{BW}$ is average body weight $(\mathrm{kg})$; AT is average time of noncarcinogenic (days); PEF is soil-to-air particulate emission factor $\left(\mathrm{m}^{3} \mathrm{~kg}^{-1}\right), \mathrm{SL}$ is soil-to-skin adherence factor $\left(\mathrm{mgcm}^{-2}\right)$; SA is skin surface area available for exposure $\left(\mathrm{cm}^{2}\right)$ and $\mathrm{ABS}$ is dermal absorption factor. Detail of these factorfor risk assessment wasindicated in Table 1.
The risk assessment for non-carcinogenic was calculated using Equation 5:

$$
H I=\sum_{i=1}^{m} \sum_{j=1}^{n} H Q_{i j}=\sum_{i=1}^{m} \sum_{j=1}^{n}\left(\frac{D}{R f D}\right)_{i j}
$$

(Eq.5)

where $m$ and $n$ are type and number of pollutants; $R_{f} D$ is reference dose $\left(\mathrm{mg} \mathrm{kg} \mathrm{day}^{-1}\right)$ (Table 1$)$; D is daily uptakedose $\left(\mathrm{mg} \mathrm{kg}^{-1} \mathrm{day}^{-1}\right)$; $\mathrm{HQ}_{\mathrm{ij}}$ is risk for the exposure path. HI $<1$ means there is no possibility of adverse human health effects, whereas HI $>1$ means there is likely to have adverse effect on human health.

Table1 Parameters used for risk assessment (Hang et al., 2009)

\begin{tabular}{lcc}
\hline \multicolumn{1}{c}{ Parameters } & Adult & Children \\
\hline IngR & 100 & 200 \\
-Soil $\left(\right.$ mgday $\left.^{-1}\right)$ & 389.2 & 198.4 \\
- Rice grain $(\mathrm{g}$ & & \\
day $\left.^{-1}\right)$ & 12.8 & 7.63 \\
InhR $\left(\mathrm{m}^{3} \mathrm{day}^{-1}\right)$ & 350 & 320 \\
EF (day) & 24 & 6 \\
ED (year) & 59.95 & 23.9 \\
BW $\left(\mathrm{kg}^{-1}\right.$ & 8,760 & 2,190 \\
AT $($ day $)$ & 2,145 & 1,150 \\
SA $\left(\mathrm{cm}^{2}\right)$ & 0.07 & 0.20 \\
SL $\left(\mathrm{mg} \mathrm{cm}^{-2}\right)$ & 0.001 & 0.001 \\
ABS & $1.36 \mathrm{E}+09$ & $1.36 \mathrm{E}+09$ \\
PEF $\left(\mathrm{m}^{3} \mathrm{~kg}^{-1}\right)$ &
\end{tabular}

Table.2: Reference doses of some heavy metalsFerreiraBaptista and de Miguel (2005)

\begin{tabular}{cccc}
\hline Heavy & \multicolumn{3}{c}{${\text { RfD }\left(\mathbf{m g ~ k g}^{-1} \mathbf{d a y}^{\mathbf{1}}\right)}^{\text {metals }}$} \\
\cline { 2 - 4 } & RfD $_{\text {ing }}$ & RfD $_{\text {inh }}$ & RfD $_{\text {der }}$ \\
$\mathrm{Cd}$ & $1.00 \mathrm{E}-03$ & & $1.00 \mathrm{E}-05$ \\
$\mathrm{Cr}$ & $3.00 \mathrm{E}-03$ & $2.86 \mathrm{E}-05$ & $6.00 \mathrm{E}-05$ \\
$\mathrm{Cu}$ & $4.00 \mathrm{E}-02$ & $4.02 \mathrm{E} 02$ & $1.20 \mathrm{E}-02$ \\
$\mathrm{Mn}$ & $4.60 \mathrm{E}-02$ & $1.43 \mathrm{E}-05$ & $1.84 \mathrm{E}-03$ \\
$\mathrm{Ni}$ & $2.00 \mathrm{E}-02$ & $2.06 \mathrm{E}-02$ & $5.40 \mathrm{E}-03$ \\
$\mathrm{~Pb}$ & $1.40 \mathrm{E}-03$ & $3.52 \mathrm{E}-05$ & $5.25 \mathrm{E}-05$ \\
$\mathrm{Zn}$ & $3.00 \mathrm{E}-01$ & $3.00 \mathrm{E}-01$ & $6.00 \mathrm{E}-02$ \\
\hline
\end{tabular}




\section{RESULTS AND DISCUSSION}

\section{1) Occurrence of heavy metals in soil}

Table 3 presented the concentrations of heavy metals in the soil surrounding the landfill. Six out of seven heavy metals occurred in the two soil layers around the landfill with average concentrations ranging from $12.3 \pm$ $2.14-291 \pm 38.85 \mathrm{mg} \mathrm{kg}^{-1}$. The concentrations of $\mathrm{Mn}, \mathrm{Zn}$, $\mathrm{Cu}, \mathrm{Cr}$ at the locations $\mathrm{S} 1, \mathrm{~S} 2$ and S3 were all higher than those at $\mathrm{S} 4$ (1 km away from the landfill). Cd was the only metal not detected in all soil samples.

Table.3: Heavy metals concentrations in the soilsurrounding the landfill

\begin{tabular}{|c|c|c|c|c|c|c|c|}
\hline \multirow[b]{2}{*}{$\begin{array}{l}\text { Heavy } \\
\text { metals }\end{array}$} & \multicolumn{5}{|c|}{ Heavy metal concentration $\left(\mathrm{mg} \mathrm{kg}^{-1}\right)$} & \multirow{2}{*}{$\begin{array}{c}\text { QCVN 03- } \\
\text { MT:2015/BT } \\
\text { NMT }\end{array}$} & \multirow[b]{2}{*}{$\begin{array}{c}\text { CCME } \\
2007\end{array}$} \\
\hline & S1 & $\mathbf{S 2}$ & S3 & S4 & $\begin{array}{c}\text { Average } \\
\text { (S1, S2, } \\
\text { S3) }\end{array}$ & & \\
\hline $\mathrm{Mn}$ & $321^{\mathrm{a}} \pm 2$ & $240^{\mathrm{b}} \pm 0$ & $315^{\mathrm{a}} \pm 2$ & $234^{\mathrm{b}} \pm 8$ & $\begin{array}{l}291 \pm \\
38.85\end{array}$ & - & - \\
\hline $\mathrm{Zn}$ & $78.8^{\mathrm{b}} \pm 0$ & $\begin{array}{c}82.7^{\mathrm{a}} \pm \\
0.70\end{array}$ & $\begin{array}{c}65.8^{\mathrm{d}} \pm \\
0.35\end{array}$ & $74.7^{\mathrm{c}} \pm 0$ & $75.8 \pm 7.70$ & 200 & 200 \\
\hline $\mathrm{Cu}$ & $20.4^{\mathrm{a}} \pm 0$ & $\begin{array}{c}19.0^{\mathrm{b}} \pm \\
0.27\end{array}$ & $\begin{array}{c}14.7^{\mathrm{d}} \pm \\
0.01\end{array}$ & $17.6^{\mathrm{c}} \pm 0$ & $18.1 \pm 2.66$ & 100 & 63 \\
\hline $\mathrm{Cr}$ & $9.66^{c} \pm 0.56$ & $\begin{array}{c}27.5^{\mathrm{a}} \pm \\
0.70\end{array}$ & $\begin{array}{c}28.3^{\mathrm{a}} \pm \\
0.05\end{array}$ & $11.1^{\mathrm{b}} \pm 0.4$ & $21.8 \pm 9.12$ & 150 & 64 \\
\hline $\mathrm{Ni}$ & $34.9^{\mathrm{b}} \pm 0$ & $\begin{array}{c}36.3^{\mathrm{a}} \pm \\
0.50\end{array}$ & $\begin{array}{c}30.5^{\mathrm{c}} \pm \\
0.25\end{array}$ & $\begin{array}{c}35.6^{\mathrm{b}} \pm \\
0.45\end{array}$ & $33.9 \pm 2.66$ & - & 50 \\
\hline $\mathrm{Pb}$ & $14.6^{\mathrm{a}} \pm 0.03$ & $\begin{array}{c}12.6^{\mathrm{c}} \pm \\
0.02\end{array}$ & $\begin{array}{c}9.66^{\mathrm{d}} \pm \\
0.08\end{array}$ & $\begin{array}{c}13.1^{\mathrm{b}} \pm \\
0.50\end{array}$ & $12.3 \pm 2.14$ & 70 & 70 \\
\hline $\mathrm{Cd}$ & ND & ND & ND & ND & ND & - & $3^{\mathrm{a}}$ \\
\hline
\end{tabular}

Notes: Data were presented as Mean $\pm \mathrm{SD}, \mathrm{n}=3$. Diffrerent letters ${ }^{\mathrm{a}, \mathrm{b}, \mathrm{c}}$ indicated statistically significant at significance level

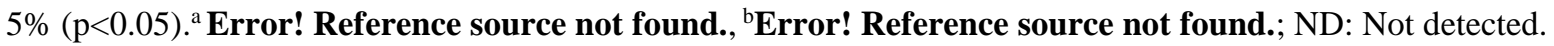

Most of heavy metal concentrations in soil were in compliance with QCVN 03-MT: 2015/BTNMT, CCME (2007). Concentration of $\mathrm{Mn}$ was the metal with the highest concentrations in soil ranging from $240 \pm 0-321 \pm$ $2 \mathrm{mg} \mathrm{kg}^{-1}$ (Table 3). Mn concentrations at S1 and S3 were always higher than that at $\mathrm{S} 4$ showing the negative impact of the landfill leachate on soil environment. Similar to Mn, $\mathrm{Cr}$ concentration at S4 was lower than those at S2 and S3 and this could be because $\mathrm{Cr}$ is not directly affected by the landfill leachate. The presence of $\mathrm{Cr}$ in soil is a major threat to plants and humans because under appropriate environmental conditions, $\mathrm{Cr}$ (III) is easily converted to $\mathrm{Cr}$ (VI) - a form always toxic to plants (Ba, 2008). At locations around the landfill sites (except S3), Ni concentration ranging from $30.5 \pm 0.25-36.3 \pm 0.50 \mathrm{mg}$ $\mathrm{kg}^{-1}$. The results of $\mathrm{Zn}$ concentration ranged from $65.8 \pm$ $0.35-82.7 \pm 0.70 \mathrm{mg} \mathrm{kg}^{-1}$. The distribution of $\mathrm{Ni}$ and $\mathrm{Zn}$ concentration at the locations and the soil were mainly influenced by the impact of leachate, mobility of the metals and soil properties. $\mathrm{Cu}$ and $\mathrm{Pb}$ were presented in soil with relatively low concentration at $16.3 \pm 2.20-18.1 \pm 2.66$ $\mathrm{mg} \mathrm{kg}^{-1}$ and $11.2 \pm 0.46-12.3 \pm 2.14 \mathrm{mg} \mathrm{kg}^{-1}$, respectively (Table 3$)$. Pb concentration in the soilat $\mathrm{S} 4(13.1 \pm 0.50 \mathrm{mg}$ $\left.\mathrm{kg}^{-1}\right)$ was higher than those at S1-S3 (9.66 $\pm 0.08-12.6 \pm$ $\left.0.02 \mathrm{mg} \mathrm{kg}^{-1}\right)$. Six out of seven heavy metals occurred in the soil samples collected at the surrounding landfill and $1 \mathrm{~km}$ away from landfill. The presence of heavy metals not only affects the quality of the soil but also threatens the groundwater and rice production.

\section{2) Heavy metals in rice plant}

It was found that six out of seven heavy metals occurred in the rice plant parts including root, stem-leave, and rice grain (Table 4). The $\mathrm{Cd}$ concentration was below the detection limit, and below the FAO/WHO regulatory standard $\left(0.2 \mathrm{mg} \mathrm{kg}^{-1}\right)$. Heavy metals were found highly accumulated in the rice roots in this study (Table 4). The concentrations of $\mathrm{Mn}, \mathrm{Zn}, \mathrm{Cu}, \mathrm{Pb}, \mathrm{Ni}$ and $\mathrm{Cr}$ in the rice root at S1-S3 were $674 \pm 12.53 \mathrm{mg} \mathrm{kg}^{-1}, 87.6 \pm 0.93 \mathrm{mg}$ 
$\mathrm{kg}^{-1}, 29.3 \pm 0.20 \mathrm{mg} \mathrm{kg}^{-1}, 11.7 \pm 0.07 \mathrm{mg} \mathrm{kg}^{-1}, 16.9 \pm 0.68$ $\mathrm{mg} \mathrm{kg}^{-1}$ and $10.4 \pm 0.06 \mathrm{mg} \mathrm{kg}^{-1}$, respectively, while these heavy metals at $\mathrm{S} 4$ were $403 \pm 6.66 \mathrm{mg} \mathrm{kg}^{-1}, 104 \pm 2.08$ $\mathrm{mg} \mathrm{kg}-1,28.0 \pm 1.85 \mathrm{mg} \mathrm{kg}^{-1}, 14.5 \pm 0.80 \mathrm{mg} \mathrm{kg}^{-1}, 7.95 \pm$ $0.34 \mathrm{mg} \mathrm{kg}^{-1}$ and $5.04 \pm 0.09 \mathrm{mg} \mathrm{kg}^{-1}$, respectively (Table 4). The results indicated that heavy metal concentrations in rice roots in the area influenced by the landfill leachate were higher than those without influenced by the landfill activity.
The heavy metals including $\mathrm{Mn}, \mathrm{Zn}, \mathrm{Cu}, \mathrm{Ni}$, and $\mathrm{Cr}$ at the locations surrounding the landfills (S1-S3) were detected in the stem and leave of the rice plants at the concentrations of $645 \pm 8.72 \mathrm{mg} \mathrm{kg}^{-1}, 47.6 \pm 1.08 \mathrm{mg} \mathrm{kg}^{-1}$, $5.42 \pm 0.34 \mathrm{mg} \mathrm{kg}^{-1}, 4.37 \pm 0.16 \mathrm{mg} \mathrm{kg}^{-1}, 2.30 \pm 0.05 \mathrm{mg}$ $\mathrm{kg}^{-1}$, respectively. There were only $\mathrm{Mn}, \mathrm{Zn}, \mathrm{Ni}$ and $\mathrm{Cu}$ found at $\mathrm{S} 4$ at the concentrations of $544 \pm 15.87 \mathrm{mg} \mathrm{kg}^{-1}$, $61.5 \pm 0.55 \mathrm{mg} \mathrm{kg}^{-1}, 2.78 \pm 0.09 \mathrm{mg} \mathrm{kg}^{-1}$ and $1.96 \pm 0.82$ $\mathrm{mg} \mathrm{kg}^{-1}$, respectively (Table 4).

Table.4: Concentrations of heavy metals in rice plants

\begin{tabular}{cllll}
\hline \multirow{2}{*}{$\begin{array}{c}\text { Sampling } \\
\text { sites }\end{array}$} & \multirow{2}{*}{ Heavy metals } & \multicolumn{3}{c}{ Concentration of heavy metals $\left(\mathbf{m g ~ k}^{-\mathbf{1}}\right)$} \\
\cline { 3 - 5 } & $\mathrm{Mn}$ & $403^{\mathrm{b}} \pm 6.66$ & $544^{\mathrm{a}} \pm 15.87$ & \multicolumn{1}{c}{ Grains } \\
\hline & $\mathrm{Zn}$ & $104^{\mathrm{a}} \pm 2.08$ & $61.5^{\mathrm{b}} \pm 0.55$ & $129^{\mathrm{c}} \pm 11.59$ \\
& $\mathrm{Cu}$ & $28.0^{\mathrm{a}} \pm 1.85$ & $1.96^{\mathrm{b}} \pm 0.82$ & $1.47^{\mathrm{c}} \pm 0.82$ \\
$\mathrm{~S} 4$ & $\mathrm{Cr}$ & $5.04 \pm 0.09$ & $\mathrm{ND}$ & $0.57 \pm 0.01$ \\
& $\mathrm{Ni}$ & $7.95^{\mathrm{a}} \pm 0.34$ & $2.78^{\mathrm{b}} \pm 0.09$ & $1.68^{\mathrm{c}} \pm 0.30$ \\
& $\mathrm{~Pb}$ & $14.5 \pm 0.80$ & $\mathrm{ND}$ & $\mathrm{ND}$ \\
& $\mathrm{Cd}$ & $\mathrm{ND}$ & $\mathrm{ND}$ & $\mathrm{ND}$ \\
\hline & $\mathrm{Mn}$ & $674^{\mathrm{a}} \pm 12.53$ & $645^{\mathrm{a}} \pm 8.72$ & $237^{\mathrm{b}} \pm 21.79$ \\
& $\mathrm{Zn}$ & $87.6^{\mathrm{a}} \pm 0.93$ & $47.6^{\mathrm{b}} \pm 1.08$ & $35.8^{\mathrm{c}} \pm 0.17$ \\
$\mathrm{Su} 1-\mathrm{S} 3$ & $29.3^{\mathrm{a}} \pm 0.20$ & $5.42^{\mathrm{b}} \pm 0.34$ & $4.27^{\mathrm{c}} \pm 0.07$ \\
& $\mathrm{Cu}$ & $10.4^{\mathrm{a}} \pm 0.06$ & $2.30^{\mathrm{c}} \pm 0.05$ & $5.67^{\mathrm{b}} \pm 0.25$ \\
& $\mathrm{Cr}$ & $16.9^{\mathrm{a}} \pm 0.68$ & $4.37^{\mathrm{b}} \pm 0.16$ & $4.25^{\mathrm{b}} \pm 0.13$ \\
& $\mathrm{Ni}$ & $11.7 \pm 0.07$ & $\mathrm{ND}$ & $\mathrm{ND}$ \\
& $\mathrm{Pb}$ & $\mathrm{ND}$ & $\mathrm{ND}$ & $\mathrm{ND}$ \\
\hline
\end{tabular}

Notes: Data were presented as Mean $\pm S D, n=3$. Diffrerent letters ${ }^{a, b, c}$ indicated statistically significant at significance level $5 \%(p<0.05)$. ND: not detected.

The concentrations of $\mathrm{Mn}, \mathrm{Zn}, \mathrm{Cr}, \mathrm{Cu}$ and $\mathrm{Ni}$ in the rice grains surrounded the landfill were $237 \pm 21.79 \mathrm{mg}$ $\mathrm{kg}^{-1}, 35.8 \pm 0.17 \mathrm{mg} \mathrm{kg}^{-1}, 5.67 \pm 0.25 \mathrm{mg} \mathrm{kg}^{-1}, 4.27 \pm 0.07$ $\mathrm{mg} \mathrm{kg} \mathrm{kg}^{-1}, 4.25 \pm 0.13 \mathrm{mg} \mathrm{kg}^{-1}$, respectively. At the $\mathrm{S} 4$ location, the concentrations of $\mathrm{Mn}, \mathrm{Zn}, \mathrm{Ni}, \mathrm{Cu}$ and $\mathrm{Cr}$ in the rice grains were $129 \pm 11.59 \mathrm{mg} \mathrm{kg}^{-1}, 17.7 \pm 0.82 \mathrm{mg}$ $\mathrm{kg}^{-1}, 1.68 \pm 0.30 \mathrm{mg} \mathrm{kg}^{-1}, 1.45 \pm 0.13 \mathrm{mg} \mathrm{kg}^{-1}$ and $0.57 \pm$ $0.01 \mathrm{mg} \mathrm{kg}^{-1}$, respectively. The average concentration of heavy metals in the rice grains at the locations S1-S3 were significantly higher than those at $\mathrm{S} 4$ from 1.49 - 2.94 times. The concentration of $\mathrm{Cr}$ in rice grainat $\mathrm{S} 1-\mathrm{S} 3$ (near the landfill)was 10 time higher than that at S4 (1 km away from the landfill) could indicate serious impact of landfill leachate on the rice production and pose a threat to rice consumption since $\mathrm{Cr}$ is considered carcinogenic metal (Ba, 2008).

Among the heavy metals, Mn was highly accumulated in rice plants that could be due to its higher mobility compared to the others (Prechthai et al., 2008). This study found that accumulation of heavy metals in parts of rice at S1-S3 was higher that those at S4 (except for $\mathrm{Zn}$ and $\mathrm{Pb}$ at rice roots) and decreased in the order $\mathrm{Mn}>$ $\mathrm{Zn}>\mathrm{Cu}>\mathrm{Ni}>\mathrm{Cr}$ (except in rice grain, $\mathrm{Cr}>\mathrm{Cu}>\mathrm{Ni}$ ). Heavy metals accumulated in rice parts with decreasing order root> stem - leave>grain (except for Mn at S4 and Cr at S1 - S3).

\section{3) Health risk assessment}

The mean concentration of heavy metals found in soils and rice grainswere used to calculate health risk and the results were showed in Table 5.

Health risk assessment was performed for heavy metals contaminated in soil and rice grains. The result indicated that there is no health risk for children and adults since all the hazard indexes (HI) were less than 1. Children were likely to suffer more risk than adults because the HI values for children were higher than adults (Table 5). Previous studies also indicated that there was no possible risk for human when exposed to soil and rice grains contaminated with heavy metals surrounding the landfill $[13,20]$. It was clearly showed that HI values calculated 
for the heavy metals in the area surrounding the landfill (S1-S3) were higher than those calculated for heavy metals at the location S4 (Table 5). This could mean that higher health risk was expected for the area around the landfill. In the soil sample, the level of health risk (for adult) gradually decreases via $\mathrm{HQ}_{\mathrm{ing}}>\mathrm{HQ}_{\mathrm{inh}}>\mathrm{HQ}_{\text {der }}$ routes; However, the potential health risk for children via ingestion $\left(\mathrm{HQ}_{\mathrm{der}}\right)$ was higher that that via inhalation $\left(\mathrm{HQ}_{\mathrm{inh}}\right)$. Among the heavy metals, $\mathrm{Pb}$ was the metal could pose the highest health risk, although this is the metal present with the lowest concentration in the soil. The health risk levels of the examined heavy metals were arranged as decreasing order $\mathrm{Pb}>\mathrm{Mn}>\mathrm{Cr}>\mathrm{Ni}>\mathrm{Cu}>\mathrm{Zn}$. In the rice grains, the estimated potential health risk of the heavy metals were in the order of $\mathrm{Mn}>\mathrm{Cr}>\mathrm{Ni}>\mathrm{Zn}>\mathrm{Cu}$. Comparing the values of $\mathrm{HI}$ between soil and rice grains in both child and adult, it could be seen that the risk for rice grain consumption was higher than the human exposed to the soil contaminated heavy metals. This study suggested that the agricultural activity, especially rice cultivation in the area surrounding the landfill is no longer suitable because the soil was contaminated with heavy metals and the heavy metals started to be accumulated in the rice parts. Long-term consumption of agricultural products produced in the study area could lead to potential health risk.

Table.5: Health risk assessment for exposure to heavy metals contaminated soil and rice grain

\begin{tabular}{|c|c|c|c|c|c|c|c|}
\hline $\begin{array}{l}\text { Heavy } \\
\text { metals }\end{array}$ & $\mathrm{Cr}$ & $\mathbf{C u}$ & Mn & $\mathbf{N i}$ & $\mathbf{P b}$ & $\mathbf{Z n}$ & Total \\
\hline \multicolumn{8}{|c|}{ For soil sample at S4 } \\
\hline \multicolumn{8}{|c|}{ Adult } \\
\hline $\mathrm{HQ}_{\text {ing }}$ & $5.92 \mathrm{E}-03$ & $7.05 \mathrm{E}-04$ & $8.14 \mathrm{E}-03$ & $2.84 \mathrm{E}-03$ & $1.50 \mathrm{E}-02$ & $3.98 \mathrm{E}-04$ & 3.30E-02 \\
\hline $\mathrm{HQ}_{\text {inh }}$ & 5.84E-05 & $6.60 \mathrm{E}-08$ & $2.46 \mathrm{E}-03$ & $2.60 \mathrm{E}-07$ & $5.62 \mathrm{E}-07$ & $3.75 \mathrm{E}-08$ & 2.52E-03 \\
\hline $\mathrm{HQ}_{\mathrm{der}}$ & 4.44E-04 & $3.53 \mathrm{E}-06$ & $3.05 \mathrm{E}-04$ & $1.58 \mathrm{E}-05$ & $6.01 \mathrm{E}-04$ & 2.99E-06 & 1.37E-03 \\
\hline HI & $6.42 \mathrm{E}-03$ & 7.09E-04 & 1.09E-02 & $2.86 \mathrm{E}-03$ & $1.56 \mathrm{E}-02$ & 4.01E-04 & 3.69E-02 \\
\hline \multicolumn{8}{|c|}{ Children } \\
\hline $\mathrm{HQ}_{\text {ing }}$ & 2.71E-02 & $3.23 \mathrm{E}-03$ & $3.73 \mathrm{E}-02$ & $1.30 \mathrm{E}-02$ & $6.89 \mathrm{E}-02$ & $1.83 \mathrm{E}-03$ & 1.51E-01 \\
\hline $\mathrm{HQ}_{\text {inh }}$ & 8.79E-05 & 9.93E-08 & $3.70 \mathrm{E}-03$ & $3.91 \mathrm{E}-07$ & $8.45 \mathrm{E}-07$ & $5.64 \mathrm{E}-08$ & 3.79E-03 \\
\hline $\mathrm{HQ}_{\mathrm{der}}$ & $1.56 \mathrm{E}-03$ & $1.24 \mathrm{E}-05$ & $1.07 \mathrm{E}-03$ & $5.56 \mathrm{E}-05$ & $2.11 \mathrm{E}-03$ & $1.05 \mathrm{E}-05$ & 4.82E-03 \\
\hline HI & $2.88 \mathrm{E}-02$ & $3.24 \mathrm{E}-03$ & $4.21 \mathrm{E}-02$ & $1.31 \mathrm{E}-02$ & $7.08 \mathrm{E}-02$ & $1.84 \mathrm{E}-03$ & 1.60E-01 \\
\hline \multicolumn{8}{|c|}{ For soil samples at S1-S3 } \\
\hline \multicolumn{8}{|c|}{ Adult } \\
\hline $\mathrm{HQ}_{\text {ing }}$ & $1.16 \mathrm{E}-02$ & $7.22 \mathrm{E}-04$ & $1.01 \mathrm{E}-02$ & $2.71 \mathrm{E}-03$ & $1.40 \mathrm{E}-02$ & $4.04 \mathrm{E}-04$ & 3.96E-02 \\
\hline $\mathrm{HQ}_{\text {inh }}$ & $1.15 \mathrm{E}-04$ & $6.76 \mathrm{E}-08$ & $3.07 \mathrm{E}-03$ & $2.48 \mathrm{E}-07$ & $5.25 \mathrm{E}-07$ & $3.80 \mathrm{E}-08$ & 3.19E-03 \\
\hline $\mathrm{HQ}_{\mathrm{der}}$ & 8.73E-04 & $3.61 \mathrm{E}-06$ & $3.81 \mathrm{E}-04$ & $1.51 \mathrm{E}-05$ & $5.61 \mathrm{E}-04$ & $3.03 \mathrm{E}-06$ & 1.84E-03 \\
\hline HI & $1.26 \mathrm{E}-02$ & $7.25 \mathrm{E}-04$ & $1.36 \mathrm{E}-02$ & $2.73 \mathrm{E}-03$ & $1.46 \mathrm{E}-02$ & 4.07E-04 & 4.46E-02 \\
\hline \multicolumn{8}{|c|}{ Children } \\
\hline $\mathrm{HQ}_{\text {ing }}$ & $5.33 \mathrm{E}-02$ & $3.31 \mathrm{E}-03$ & $4.65 \mathrm{E}-02$ & $1.24 \mathrm{E}-02$ & $6.43 \mathrm{E}-02$ & $1.85 \mathrm{E}-03$ & 1.82E-01 \\
\hline $\mathrm{HQ}_{\text {inh }}$ & $1.73 \mathrm{E}-04$ & $1.02 \mathrm{E}-07$ & $4.62 \mathrm{E}-03$ & $3.72 \mathrm{E}-07$ & $7.89 \mathrm{E}-07$ & $5.72 \mathrm{E}-08$ & 4.79E-03 \\
\hline $\mathrm{HQ}_{\mathrm{der}}$ & $3.07 \mathrm{E}-03$ & $1.27 \mathrm{E}-05$ & $1.33 \mathrm{E}-03$ & $5.30 \mathrm{E}-05$ & $1.98 \mathrm{E}-03$ & $1.07 \mathrm{E}-05$ & $6.45 \mathrm{E}-03$ \\
\hline HI & $5.65 \mathrm{E}-02$ & $3.33 \mathrm{E}-03$ & $5.24 \mathrm{E}-02$ & $1.25 \mathrm{E}-02$ & $6.64 \mathrm{E}-02$ & $1.86 \mathrm{E}-03$ & 1.93E-01 \\
\hline \multicolumn{8}{|c|}{ For rice grain at $\mathrm{S} 4$} \\
\hline \multicolumn{8}{|c|}{ Adult } \\
\hline HI & $1.18 \mathrm{E}-03$ & $2.26 \mathrm{E}-04$ & $1.75 \mathrm{E}-02$ & 5.23E-04 & - & $3.67 \mathrm{E}-04$ & 1.98E-01 \\
\hline
\end{tabular}




\begin{tabular}{|c|c|c|c|c|c|c|c|}
\hline $\begin{array}{l}\text { Heavy } \\
\text { metals }\end{array}$ & $\mathrm{Cr}$ & $\mathbf{C u}$ & Mn & $\mathbf{N i}$ & $\mathbf{P b}$ & $\mathbf{Z n}$ & Total \\
\hline \multicolumn{8}{|c|}{ Children } \\
\hline HI & $1.38 \mathrm{E}-03$ & $2.64 \mathrm{E}-04$ & $2.04 \mathrm{E}-02$ & $6.11 \mathrm{E}-04$ & - & 4.29E-04 & 2.31E-01 \\
\hline \multicolumn{8}{|c|}{ For rice grain at $\mathrm{S1-S3}$} \\
\hline \multicolumn{8}{|c|}{ Adult } \\
\hline $\mathrm{HI}$ & $1.18 \mathrm{E}-02$ & $6.65 \mathrm{E}-04$ & $3.21 \mathrm{E}-02$ & $1.32 \mathrm{E}-03$ & - & 7.43E-04 & $4.66 \mathrm{E}-01$ \\
\hline \multicolumn{8}{|c|}{ Children } \\
\hline HI & $1.38 \mathrm{E}-02$ & 7.77E-04 & $3.75 \mathrm{E}-02$ & $1.55 \mathrm{E}-03$ & - & 8.68E-04 & $5.44 \mathrm{E}-01$ \\
\hline
\end{tabular}

\section{CONCLUSION}

Six out of seven heavy metals including $\mathrm{Mn}, \mathrm{Zn}$, $\mathrm{Ni}, \mathrm{Cr}, \mathrm{Cu}$ and $\mathrm{Pd}$ were detected and were lower than the permitted limits of QCVN 03-MT: 2015/BTNMT and CCME. The concentration of the detected heavy metals in the topsoil $(0-25 \mathrm{~cm})$ around the landfill $(\mathrm{S} 1-\mathrm{S} 3)$ were higher than those at the location $1 \mathrm{~km}$ from the landfill (S4) with the exception for $\mathrm{Ni}, \mathrm{Pb}$. The concentration of the heavy metals in the rice parts in the surrounding landfill sites decreased from $\mathrm{Mn}>\mathrm{Zn}>\mathrm{Cu}>\mathrm{Ni}>\mathrm{Cr}$ (except for the heavy metals in the rice grains with the order of $\mathrm{Cr}>\mathrm{Cu}>$ $\mathrm{Ni}$ ). $\mathrm{Cd}$ was not detected in the rice and $\mathrm{Pb}$ only appeared in the rice roots. The calculation of the hazard index (HI) shows that the health risk due to heavy metals contamination in soil and rice grain for children was higher than for adult, however, all HI values fell into safe level. Health risk for rice consumption was higher than that for exposure to soil contaminating heavy metals. In addition, health risk for due to exposure to heavy metals by all routes in the area surrounding the landfill were higher than that at $1 \mathrm{~km}$ away from the landfill. Measures should be taken to minimize the leakage of leachate into rice fields.

\section{REFERENCES}

[1] Ministry of Natural Resources and Environment. Vietnam state of environment report for the period 2011-2015, 2015.

[2] People's Committee of Can Tho City. Report on state of environment in Can Tho city in the period of $2011-2015$, 2015.

[3] Fatta, D., Papadopoulos, A., Loizidou, M. A study on the landfill leachate and its impact on the groundwater quality of the greater area. Environ Geochem Health, 1999, 21(2), 175190.

[4] Nhien, H.T.H., Giao, N.T. Environmental Soil, Water, and Sediment Quality of Dong Thang Landfill in Can Tho City, Vietnam. Applied Environmental Research, 2019, 41(2), 7383.

[5] Alam, S.S., Osman, K.T., Kibria, G. Heavy metal pollution of soil from industrial and municipal wastes in Chittagong,
Bangladesh. Archives of Agronomy and Soil Science, 2012, 58(12), 1427-38.

[6] Nava-Martinez, E.C., Flores-Garcia, E., Espinoza-Gomez, H., Wakida, F.T. Heavy metals pollution in the soil of an irregular urban settlement built on a former dumpsite in the city of Tijuana, Mexico. Environmental Earth Sciences, 2012, 66(4), 1239-1245.

[7] Ajah, K.C., Ademiluyi, J., Nnaji, C.C. Spatiality, seasonality and ecological risks of heavy metals in the vicinity of a degenerate municipal central dumpsite in Enugu, Nigeria. Journal of Environmental Health Science and Engineering, 2015,13, 1-14.

[8] Kingsawat, R., Roachanakanan, R. Accumulation and distribution of some heavy metals in water, soil and rice fields along the Pradu and Phi Lok canals, Samut Songkhram province, Thailand. Environment and Natural Resources, 2011, 9(1), 38-48.

[9] Liu, J., Li, K., Xu, J., Zhang, Z., Ma, T. Lead toxicity, uptake and translocation in different rice cultivars. Plant Science, 2003, 165, 793-802.

[10] Munees, A., Abdul, M. Bioaccumulation of heavy metals by $\mathrm{Zn}$ resistant bacteria isolated from agricultural soils irrigated with waste water. Bacteriology Journal, 2012, 2(1), 12-21.

[11] Klinsawathom, T., Songsakunrungrueng, B., Pattanamahakul, P. Heavy Metal Concentration and Risk Assessment of Soil and Rice in and around an Open Dumpsite in Thailand. EnvironmentAsia, 2017, 10(2), 5364.

[12] Satachon, P., Keawmoon, S., Rengsungnoen, P., Thummajitsakul, S., Silprasit, K. Source and Health Risk Assessment of Some Heavy Metals in Non-Certified Organic Rice Farming at Nakhon Nayok Province, Thailand. Applied Environmental Research, 2019, 41(3), 96106.

[13] Kanmani, S., Gandhimathi, R. Assessment of heavy metal contamination in soil due to leachate migration from an open dumpingsite. Applied Water Science, 2013, 3(1), 193-205.

[14] Huang, Z., Pan, X.D., Wu, P.G., Han, J.L., Chen, Q. Health Risk Assessment of Heavy Metals in Rice to the Population in Zhejiang, China. PLoS ONE, 2013, 8(9), e75007.

[15] Hang, X., Wang, H., Zhou, J., Ma, C., Du, C., Chen, X. Risk assessment of potentially toxic element pollution in soil and 
rice (Oryza sativa) in a typical area of the Yangtze River delta. Environmental Pollution, 2009,157 (8-9), 2542-2549.

[16] Ferreira-Baptista, L., de Miguel, E. Geochemistry and risk assessment of street dust in Luanda, Angola: a tropical urban environment. Atmospheric Environment, 2005, 39(25), 4501-4512.

[17] Ministry of Natural Resources and Environment. QCVN $03-$ MT: 2015/BTNMT National technical regulation on the allowable limits of heavy metals in the soil, 2015.

[18] Canadian Council of Ministers of the Environment. Soil quality guidelines for the protection of environmental and human health. CCME, 2007.

[19] Ba, L.H. Fundamental on Environmental Toxicology, third edition. Ho Chi Minh City: Ho Chi Minh City National University Press, 2008, 639 pages.

[20] Prechthai, T., Parkpian, P., Visvanathan, C. Assessment of heavy metal contamination and its mobilization from municipal solid waste open dumping site. Journal of Hazardous Materials, 2008, 156(1-3), 86-94. 